\title{
A legjelentősebb angiogeneticus gének méhlepényi expressziójának változásai a méhen belüli növekedési visszamaradás hátterében
}

\author{
Kovács Péter dr. ${ }^{1}$ - Rab Attila dr. ${ }^{2}$ - Szentpéteri Imre dr. ${ }^{3}$ \\ Joó József Gábor dr. ${ }^{4}$ - Kornya László dr. ${ }^{5}$ \\ ${ }^{1}$ Clinical Research Unit Hungary, Szikszó \\ ${ }^{2}$ Landeskrankenhaus Feldkirch, Austria \\ ${ }^{3}$ Praxis für Gynäkologie und Geburtshilfe und allgemeine Medizin, Wehingen, Baden-Württemberg, Germany \\ ${ }^{4}$ Semmelweis Egyetem, Általános Orvostudományi Kar, I. Szülészeti és Nőgyógyászati Klinika, Budapest \\ ${ }^{5}$ Egyesített Szent István és Szent László Kórház, Szülészet-Nőgyógyászati Osztály, Budapest
}

\begin{abstract}
A placentaris vascular endothelial growth factor A és endoglin gének placentaris aktivitása a méhen belüli növekedési visszamaradással járó terhességekben az eutróf magzati növekedéssel járó terhességekhez képest fokozott. E jelenség kiindulópontjaként az irodalmi adatok a placentaris endoglin aktivitás fokozódását véleményezik, amely antiangiogén hatása révén méhlepényi funkciózavar, illetve krónikus magzati hypoxia kialakulásához vezet. Ez utóbbi hatására a méhlepényi vascular endothelial growth factor A - egyfajta kompenzációként - aktivitásfokozódást mutat, amely az érképződés stimulálása révén a vérkeringési viszonyok javítását célozza. Noha az anyai serum placental growth factor szint mind méhen belüli növekedési visszamaradás, mind praeeclampsia esetén értékes prediktor lehet, méhlepényi génje a placentaris vérkeringés szabályozásában - feltehetően - kevésbé vesz rész. Orv. Hetil., 2017, 158(16), 612617.
\end{abstract}

Kulcsszavak: VEGF-A, endoglin, PlGF, méhen belüli növekedési visszamaradás, méhlepényi vérkeringés

\section{Placental gene activity of significant angiogenetic factors in the background of intrauterine growth restriction}

Placental vascular endothelial growth factor A (VEGF-A) gene and endoglin gene are both overexpressed in placental samples obtained from pregnancies with intrauterine growth restriction compared to normal pregnancies. In the background of these changes a mechanism can be supposed, in which the increased endoglin activity in intrauterine growth restriction (IUGR) leads to impaired placental circulation through an antioangiogenetic effect. This results in the development of placental vascular dysfunction and chronic fetal hypoxia. It is chronic hypoxia that turns on VEGF-A as a compensatory mechanism to improve fetal vascular blood supply by promoting placental blood vessel formation. Although the maternal serum placental growth factor (PIGF) level is a potential predictor for both IUGR and praeeclampsia, placental PlGF gene activity may be less of an active in the regulation of placental circulation in IUGR pregnancies during the later stages of gestation.

Keywords: VEGF-A, endoglin, PlGF, intrauterine retardation, placental circulation

Kovács, P., Rab, A., Szentpéteri, I., Joó, J. G., Kornya, L. [Placental gene activity of significant angiogenetic factors in the background of intrauterine growth restriction]. Orv. Hetil., 2017, 158(16), 612-617.

(Beérkezett: 2016. szeptember 25.; elfogadva: 2017. február 25.) 


\section{Rövidítések}

$\mathrm{CPR}=$ cerebroplacental ratio; HELLP-szindróma $=$ haemolysis, elevated liver enzymes, low platelet count; IUGR = (intrauterine growth restriction) méhen belüli növekedési visszamaradás; $\mathrm{PI}(\mathrm{mca})$ = arteria cerebri media pulsatilis index; $\mathrm{PI}(\mathrm{ua})=$ arteria uterine pulsatilis index; $\mathrm{PlGF}=$ placental growth factor; TGF-béta- $3=$ transforming growth factor beta $3 ; \mathrm{VEGF}=$ vascular endothelial growth factor; VEGF-A = vascular endothelial growth factor A; VEGF-B = vascular endothelial growth factor $\mathrm{B}$; VEGF-C = vascular endothelial growth factor $\mathrm{C}$; VEGF-D = vascular endothelial growth factor D; VEGF-E = vascular endothelial growth factor E; VEGF-F = vascular endothelial growth factor F; VEGFR-1 = vascular endothelial growth factor receptor-1; VEGFR-2 = vascular endothelial growth factor receptor 2; VEGFR-3 = vascular endothelial growth factor receptor 3

Méhen belüli növekedési visszamaradás (intrauterine growth restriction - IUGR) kórisméje akkor állítható fel, ha a magzat súlya nemének és a terhességi kornak megfelelő standard 10 percentilise alá esik [1]. A kórkép etiológiája igen összetett: a méhlepény funkciózavarán túl intrauterin infekciókra, magzati fejlődési rendellenességekre, illetve anyai tényezőkre egyaránt visszavezethető. A placentaris funkciózavar a méhlepényen keresztül történő anyag- és gáztranszport hatékonyságának csökkenését és így a magzat glükóz- és oxigénellátásának mérséklődését okozza [2-4]. Miközben a lepény működési zavara tekinthető az IUGR leggyakoribb etiológiai tényezőjének, a kórkép molekuláris szintü biológiai magyarázata egyelőre nem ismert $[5,6]$. Kialakulása elsősorban a méhlepényi keringés zavarára vezethető vissza. A keringészavar kialakulásában a placentaris érképződés anomáliái fontos szerepet játszanak [7-10].

A méhen belüli növekedési visszamaradás a perinatalis morbiditás és mortalitás egyik vezető oka [1]. Hátterében leggyakrabban a méhlepény múködési zavara áll, amely intrauterin retardáció mellett méhen belüli elhaláshoz, praeeclampsiához, illetve koraszüléshez is vezethet $[7,8]$.

Az intrauterin retardáció eseteinek felosztása a méhlepényi funkciózavar súlyossági foka alapján történik. A kórkép enyhébb eseteiben a placentaris keringés romlása lassabb; az arteria umbilicalis pulzatilis index (szisztolés maximális véráramlás-diasztolés végáramlás/átlagos véráramlási sebesség az arteria umbilicalison) értékének megemelkedése és a cerebroplacentaris arány (cerebroplacental ratio - CPR: $\mathrm{PI}(\mathrm{mca}) / \mathrm{PI}(\mathrm{ua})$; arteria cerebri media pulzatilis indexe/arteria uterine pulzatilis indexe) csökkenése között eltelt idő (medián érték: 33 nap) szignifikánsan hosszabb, mint a méhen belüli növekedési visszamaradás súlyosabb eseteiben (medián érték: 18 nap) [11]. A korai placentaris múködészavar esetén ez az időtartam akár hét napra is rövidülhet. Mindezek alapján érthető, hogy az IUGR különböző súlyosságú eseteiben a szüléskor fennálló gestatiós kor medián értékeiben is szignifikáns különbségek jelennek meg [11].
Az érképződésnek két útja ismert, a vasculogenesis és az angiogenesis; elóbbi esetben az új ér prekurzor sejtekből de novo alakul ki, míg az angiogenesis a már létező érképletek további differenciálódása (új érágak kialakulása) révén történik $[12,13]$. E két folyamat szabályozásában számos regulátorfehérje játszik szerepet, amelyek közül a vascular endothelial growth factor (VEGF) fehérjecsalád játszik különösen fontos szerepet [13-15].

\section{Vascular endothelial growth factor A (VEGF-A)}

A VEGF növekedési faktor család talán a legjelentősebb szabályozója a vasculo- és angiogenesis folyamatainak. E csoportba összesen hét fehérje tartozik, amelyeket VEGF-A (szaknyelvben: VEGF), VEGF-B, VEGF-C, VEGF-D, VEGF-E, VEGF-F, illetve placental growth factor (PlGF) névvel jelölünk [16-19]. E növekedési faktorok a jeltovábbításban a megfelelő receptorokhoz kötődve vesznek részt, amelyek a VEGFR-1 (vascular endothelial growth factor receptor) (flt-1), VEGFR-2 (KDR) és VEGFR-3 (flt-4) lehetnek [18, 20, 21].

A VEGF-proteinek receptoraikhoz kapcsolódva számos fehérje aktiválásán keresztül serkentik az endothelialis sejtek proliferációját, migrációját és így az érképződést. A VEGF-A ezen túlmenően a szöveti nitrogénmonoxid-termelés stimulálásán keresztül értágulatot előidézve serkenti az erekben a véráramlást [18, 22].

Az IUGR tartós fennállása a magzat számára perzisztáló hypoxiát jelent, amelynek hátterében a lepénybolyhok érhálózatának a megkevesbedését igazolták [10, 12]. További vizsgálatok a méhlepénybolyhok számának csökkenésén keresztül az oxigén- és energiatranszportban részt vevő érpálya összfelszínének csökkenésében azonosították a kórkép patofiziológiájának a lényegét $[23,24]$. Noha az érképződési zavar teljes mechanizmusának biológiai háttere egyelőre felderítetlen, az angiogeneticus faktorok múködészavarát több szerző is erősen valószínúsíti [12, 23-25]. Míg állatkísérletekben elsősorban a VEGF-A csökkent múködése eredményezte IUGR kialakulását, addig a humán mintán végzett vizsgálatok elsősorban a PlGF érintettségére utaló eredményeket mutattak [26-30].

Több génexpressziós vizsgálat tanúsága szerint $[7,31]$ a méhen belüli növekedési visszamaradással járó terhességekből származó méhlepényszövetben a VEGF-A génje fokozott aktivitást mutat. A kóros érképződés gyakran fordul elő méhen belüli magzati sorvadással járó terhességekben. Chen [12] vizsgálatai szerint az IUGR-rel járó terhességekből származó méhlepényszövetekben a lepénybolyhok érellátottsága szignifikánsan alacsonyabb, mint az eutróf terhességekból származó placenták esetében. Ez rosszabb placentaris keringéshez, majd tartós hypoxia kialakulásához vezet. Valószínü, hogy a placenta fokozott VEGF-A-aktivitása révén stimulált angiogenesis a tartós hypoxia kompenzációját szolgálja, ugyanak- 
kor nem pusztán a fokozott érképződést segíti elő, hanem a trophoblastmúködésre is hatást gyakorol [31].

Irodalmi adatok alapján úgy túnik, hogy a magzat neme a méhlepényi keringészavar, illetve az angiogeneticus kompenzáció kialakulásában nem játszik meghatározó szerepet [31].

A méhen belüli növekedési visszamaradás súlyossági foka szempontjából a VEGF-A gén aktivitása szignifikáns különbséget ugyancsak nem mutat. Ez arra utal, hogy az anyai szervezet önmagában a lassabb méhüri fejlődésre reagál akkor, amikor a VEGF-A génexpressziós aktivitását, s így az angiogenesist fokozza, a növekedési elmaradás mértéke már nem bír érdemi jelentőséggel [31].

Noha a rendelkezésre álló irodalmi adatok ismeretében a méhen belüli növekedési retardációban szenvedő újszülöttek méhlepényi VEGF-A-aktivitása a terhesség befejeződésekor fennálló terhességi kortól függetlenül túlmúködést mutat, nem hagyható figyelmen kívül, hogy a túlmúködés mértéke a gestatiós korral - szignifikáns különbség nélkül -, pozitív korrelációban áll [31]. Vagyis a terhesség terminusához időben közelebb véget érô terhességekben a VEGF-A placentaris aktivitása is kifejezettebb; ezt magyarázhatja a méhen belüli növekedési visszamaradás fennállásának hosszabb időtartama, amely - eróteljesebb kompenzációt igényelve - markánsabb angiogeneticus aktivitást indukál, ugyanakkor később kialakuló intrauterin retardáció esetén annak súlyos foka is magyarázatul szolgálhat, noha az IUGR súlyossága és VEGF-A génexpresszió között szignifikáns összefüggés a vonatkozó irodalmi adatok alapján nem áll fenn [31].

\section{Endoglin}

Az endoglin (CD 105) nevü membrán glikoprotein, amelyet 1990-ben fedeztek fel és írtak le elöször [32]. Kémiai szerkezetét tekintve egy 658 aminosavból álló fehérje, amely tartalmaz egy intra- és extracelluláris, illetve egy transzmembrán domént [33]. Az endoglin génje elsősorban az endothelialis sejtekben expresszálódik, de monocytákban, csontvelői sejtekben, illetve syncytiotrophoblast-sejtekben is kimutatható $[33,34]$. Az endoglin génjének mutációja az autoszomális domináns öröklésmenetû́ Osler-Weber-Rendu-kór (hereditaer haemorrhagiás teleangiectasia) kialakulásához vezet, de azonosították biológiai szerepét a tumorszöveti proliferációban is [35]. Onkológiai szempontból a multimodality imaging technique az endoglin képalkotó eljárások (ultrahangvizsgálat, MR-vizsgálat, pozitronemissziós tomográfia) révén történő kimutatását is lehetôvé teszi [35].

Az endoglin a nyugalomban lévő endothelialis sejtekben csak kismértékben expresszálódik, azonban embryogenesis, gyulladás vagy szövetsérülés esetén expressziója ugrásszerüen megnő $[36,37]$.

Újabb kutatások az endoglin biológiai hatását összefüggésbe hozzák a praeeclampsia, illetve a méhen belüli növekedési visszamaradás kialakulásával [38-41]. Ramsay hipotézise szerint mindkét kórkép hátterében a vas- cularis diszfunkció a meghatározó, ám míg praeeclampsia esetén ez szisztémás megjelenésű, addig IUGR-ben kizárólag a méhlepényre lokalizálódik [42].

További vizsgálatok szerint a méhen belüli növekedési visszamaradás esetén az endoglin anti-angiogeneticus biológiai hatása révén gátolja a VEGF (vascular endothelial growth factor) és a PlGF (placental growth factor) angiogeneticus hatását, amely méhlepényszöveti endothelialis diszfunkcióhoz vezet $[39,40,43]$.

Az IUGR tartós fennállása a magzat számára perzisztáló hypoxiát jelent, amelynek hátterében a lepénybolyhok érhálózatának a megkevesbedését igazolták. Yinon vizsgálatai azt is bizonyították, hogy az oxigén szintjének csökkenése a várandós vérében a TGF-béta-3 (transforming growth factor beta 3) révén stimulálja a placentaris endothelsejtek endoglintermelését, ami az anti-angiogeneticus hatása révén az erek funkciózavarát alakítja ki [44].

A méhen belüli növekedési visszamaradásban szenvedő újszülöttektől származó placentaris mintákban az endoglin gén az irodalmi adatok alapján szignifikáns túlmúködést mutat, ami erôteljes anti-angiogeneticus aktivitásra utal [45]. Az anti-angiogeneticus hatású, vagyis az érképződést gátló endoglin anyai szérumban mérhető szintjét már számos vizsgálat emelkedettnek találta $[40,41]$. Az érképződés zavara miatt az IUGR-rel járó terhességekből származó lepényszövetekben a méhlepénybolyhok érellátottsága szignifikánsan alacsonyabb, mint az eutróf terhességekból származó placenták esetében. Ez rosszabb lepényi keringéshez, majd tartós hypoxia kialakulásához vezet. Fentebb hivatkozott vizsgálati adatok [31] méhen belüli növekedési visszamaradás esetén az angiogeneticus hatású VEGF-A placentaris aktivitásának fokozódását igazolták, amely a vascularis diszfunkció következtében kialakult hypoxia kompenzációját szolgálhatja [45]. Ahogy erről korábban már szó került, feltételezhető, hogy a fokozott méhlepényszöveti VEGFA-aktivitás a placenta oxigénhiányra adott válasza, amelynek kialakulásában az endoglin fokozott lepényi expreszsziója kapcsán kialakuló anti-angiogeneticus hatás fontos szerepet játszhat [45].

A romló méhlepényi vérkeringés az intrauterin retardáció patomechanizmusának legfontosabb tényezője. Ennek kialakulásában az endoglin méhlepényi génexpressziójának megváltozása fontos szerepet játszhat, amely a vérkeringési viszonyok romlásán keresztül krónikus hypoxia, illetve következményes postnatalis szövődmények kialakulásában játszik szerepet.

Megjegyzendő, hogy az IUGR-hez hasonlóan etiológiai szempontból vascularis diszfunkcióra (is) visszavezethető praeeclampsiában az endoglinhez köthető antiangiogeneticus hatás kifejezettebb, mint méhen belüli növekedési visszamaradás esetén $[46,47]$.

\section{Placental growth factor (PIGF)}

A placental growth factort először 1991-ben izolálták; egy, a VEGF-családba tartozó, glikoprotein szerkezetű 
növekedési faktor, amely elsősorban a trophoblastsejtekben termelődik és az endothelialis sejtek aktiválásában, proliferációjuk, migrációjuk serkentésében játszik szerepet $[48,49]$. Valószínú, hogy a várandósság során a PIGF más angiogeneticus faktorokkal együtt az anyai spirális artériák trophoblast-inváziójának a szabályozásában nélkülözhetetlen [49]. Megváltozott trophoblastinvázió esetén számolni kell a spirális artériák elégtelen vascularis remodellingjével, amely a méhlepény csökkent vérátáramlásához vezet [50-54]. Ennek következtében számos terhespatológiai kórkép, így intrauterin retardáció, praeeclampsia, HELLP-szindróma (haemolysis, elevated liver enzymes, low platelet count) alakulhat ki.

A terhesség alatt kialakuló méhlepényi múködészavar esetleges előrejelzése nagy előrelépést jelenthetne a kórkép korai felismerése, illetve megelőzése felé. E prognosztikai lehetőséget az anyai vérkeringésben fellelhető biomarkerek jelentik, amelyek közül a PlGF az egyik legígéretesebb. Élettani terhességben szérumszintje a második trimeszter végéig fokozatosan emelkedik, majd azt követően hasonló jelleggel csökken [55]. Irodalmi adatok szerint az alacsony anyai szérum-PlGF-szint praeeclampsiában diagnosztikus értékü lelet [56], ugyanakkor egyes hipotézisek az intrauterin retardáció kialakulásával is összefüggésbe hozzák [57]. Arról megoszlanak a vizsgálati adatok, hogy a placental growth factor szintje csak praeeclampsiához társult IUGR-ben alacsonyabb-e, vagy normotensiós, de növekedésben visszamaradott magzattal várandós terhesekben is előfordul-e?

Pár évvel ezelőtti vizsgálatok felvetették - amit aztán néhány további vizsgálat is megerősített -, hogy az anyai szérum-PlGF-szint csökkenése már a várandósság első trimeszterében felvetheti a később kialakuló intrauterin retardáció vagy praeeclampsia gyanúját $[52,57]$. A legújabb vizsgálatok az anyai szérum-PlGF értékének és az arteria uterina Doppler-vizsgálattal mérhető pulsatilis indexének az együttes elemzése alapján vélelmezik a méhen belüli növekedési visszamaradás hatékony előrejelzését [58].

$\mathrm{Az}$ a törekvés, amely a méhen belüli növekedési visszamaradás előrejelzésére alkalmas szérummarker(ek) felfedezését célozza, a kutatók figyelmét egyre inkább a placental growth factor felé fordította és fordítja. Az IUGR hátterében azonosítható méhlepényi vérkeringészavar kialakulásában az angiogeneticus faktoroknak, így a PlGF-nek is markáns szerepe lehet. Feltételezték, hogy méhen belüli növekedési visszamaradás esetén a PlGF placentaris expressziója változik meg, ami komoly befolyással bírhat a méhlepényi vérkeringés alakulására is, ugyanakkor a placentaris génexpressziós vizsgálatok a PlGF-génaktivitást IUGR esetén az eutróf méhlepénymintákhoz képest szignifikánsan eltérőnek nem mutatták [59]. Mivel a VEGF-A gén expressziója IUGR-ben szenvedő magzatoktól nyert méhlepénymintákon túlmúködést mutat [31], kijelenthető, hogy placentaris angiogeneticus hatását tekintve a VEGF-A meghatározóbb hatású, mint a PlGF. Ennek alapján az is feltételezhető, hogy a placental growth factor prognosztikai értéke az anyai szérumvizsgálatok tekintetében jelentősebb, mint a méhlepényi génexpresszió vonatkozásában; utóbbi szempontból a VEGF-A megbízhatóbb markernek tűnik [59].

A méhen belül retardált magzat alulfejlettségének foka függvényében a PlGF-gén expressziós aktivitása a méhen belüli növekedési visszamaradás súlyosabb eseteiben (0-5 percentilis) szignifikáns alulmúködést mutat, az IUGR kevésbe súlyos (5-10 percentilis) eseteiben mérhető placentaris expressziós aktivitáshoz képest [59]. Ennek alapján feltételezhető, hogy az intrauterin retardáció igazán súlyos eseteiben már - az egyébként a VEGF-A-hoz képest nem különösebben szenzitív PlGF is génexpressziós aktivitáscsökkenést mutat, jelezve, hogy ezen esetekben a súlyos méhlepényi keringészavar hátterében álló angiogeneticus múködésváltozás több gén együttes aktivitásváltozásának a következménye.

\section{Következtetések}

Az intrauterin retardált újszülöttektől származó méhlepény-szövetmintákon a VEGF-A placentaris aktivitása szignifikáns emelkedést mutat, ugyanakkor a kórkép súlyossága az aktivitásváltozás mértékét nem befolyásolja.

A méhlepényszöveti endoglin génaktivitása méhen belüli növekedési visszamaradás esetén ugyancsak szignifikáns növekedést mutat. A legújabb irodalmi adatok alapján megfogalmazható hipotézis szerint az intrauterin retardáció legfőbb okát képező méhlepényi keringésromlás az endoglin fokozott aktivitásához köthető antiangiogeneticus hatás következménye, amely placentaris funkciózavarhoz és krónikus hypoxiához vezet. A krónikus hypoxia az angiogeneticus hatású és az érképződést elősegítő VEGF-A aktivitásának fokozódását stimulálja, amely kompenzációs mechanizmusnak tekinthető.

A méhlepényi PlGF-expresszió alakulása a méhen belüli növekedési visszamaradással szignifikáns kapcsolatot nem mutat, ugyanakkor az anyai szérum-PlGF értékének alakulása mind az intrauterin retardáció, mind a praeeclampsia esetén a predictio lehetséges markereként szóba jön.

A méhlepényi vérkeringés intrauterin retardáció esetén megfigyelhető változásainak genetikai hátterét tisztázandó további vizsgálatok szükségesek, amelyek e komplex rendszer még nem ismert összefüggéseit tárhatják fel.

Anyagi támogatás: A közlemény megírása anyagi támogatásban nem részesült.

Szerzôi munkamegosztás: K. P.: Irodalmi adatok áttekintése, szintetizálása. R. A., Sz. I.: Irodalomkutatás. J. J. 
G.: Irodalmi adatok áttekintése, értelmezése. K. L.: A közlemény végleges formába öntése, áttekintése. A cikk végleges változatát valamennyi szerző elolvasta és jóváhagyta.

Érdekeltségek: A szerzőknek nincsenek érdekeltségeik.

\section{Irodalom}

[1] Wollmann, H. A.: Intrauterine growth restriction: definition and etiology. Horm. Res., 1988, 49(Suppl. 2), 1-6.

[2] Economides, D. L., Nicolaides, K. H.: Blood glucose and oxygen tension levels in small-for-gestational-age fetuses. Am. J. Obstet. Gynecol., 1989, 160, 385-389.

[3] Magnusson, A. L., Powell, T., Wennergren, M., et al.: Glucose metabolism in the human preterm and term placenta of IUGR fetuses. Placenta, 2004, 25, 337-346.

[4] Marconi, A. M., Cetin, I., Davoli, E., et al.: An evaluation of fetal glucogenesis in intrauterine growth-retarded pregnancies. Me tabolism, 1993, 42, 860-864.

[5] Gluckman, P. D., Harding, J. E.: The physiology and pathophysiology of intrauterine growth retardation. Horm. Res., 1997, 48(Suppl. 1), 11-16.

[6] Sheikh, S., Satoskar, P., Bhartiya, D.: Expression of insulin-like growth factor-I and placental growth hormone mRNA in placentae: a comparison between normal and intrauterine growth retardation pregnancies. Mol. Hum. Reprod., 2001, 7, 287-292.

[7] Arroyo, J. A., Winn, V. D.: Vasculogenesis and angiogenesis in the IUGR placenta. Semin. Perinatol., 2008, 32, 172-177.

[8] Ahmed, A., Perkins, J.: Angiogenesis and intrauterine growth restriction. Baillieres Best Pract. Res. Clin. Obstet. Gynaecol., 2000, 14, 981-998.

[9] Manlik, D., Frances Evans, J., Ragolia, L.: Fetal growth restriction: pathogenic mechanisms. Clin. Obstet. Gynecol., 2006, 49, 219-222.

[10] Pardi, G., Marconi, A. M., Cetin, I.: Pathophysiology of intrauterine growth retardation: role of the placenta. Acta Paediatr Suppl., 1997, 423, 170-172.

[11] Turan, O. M., Turan, S., Baschat, A. A., et al.: Progression of Doppler abnormalities in intrauterine growth restriction. Ultrasound Obstet. Gynecol., 2008, 32, 160-167.

[12] Chen, C. P., Bajoria, R., Aplin, J. D.: Decreased vascularization and cell proliferation in placentas of intrauterine growth-restricted fetuses with abnormal umbilical artery flow velocity waveforms. Am. J. Obstet. Gynecol., 2002, 187, 764-769.

[13] Mayhew, T. M., Charnock-Jones, D. S., Kanfmann, P.: Aspects of human fetoplacental vasculogenesis and angiogenesis. III. Changes in complicated pregnancies. Placenta, 2004, 25, 127139

[14] Ferrara, N.: VEGF and the quest for tumour angiogenesis factors. Nat. Rev. Cancer, 2002, 2, 795-803.

[15] Gourvas, V., Dalpa, E., Konstantinidou, A., et al.: Angiogenic factors in placentas from pregnancies complicated by fetal growth restriction (review). Mol. Med. Rep., 2012, 6, 23-27.

[16] Demir, R., Seval, Y., Huppertz, B.: Vasculogenesis and angiogenesis in the early human placenta. Acta Histochem., 2007, 109, 257-265

[17] Ferrara, N., Gerber, H. P., LeCouter, J.: The biology of VEGF and its receptors. Nat. Med., 2003, 9, 669-676.

[18] Tammela, T., Enholm, B., Alitalo, K., et al.: The biology of vascular endothelial growth factors. Cardiovasc. Res., 2005, 65, 550563.

[19] Kotani, T., Sumigama, S., Tsuda, H., et al.: A case report of placental mesenchymal dysplasia with an increased VEGF-D expression. Placenta, 2012, 33, 888-891.
[20] Otrock, Z. K., Makarem, J. A., Shamseddine, A. I.: Vascular en dothelial growth factor family of ligands and receptors: review. Blood Cells Mol. Dis., 2007, 38, 258-268.

[21] Shore, V. H., Wang, T. H., Wang, C. L., et al.: Vascular endothelial growth factor, placenta growth factor and their receptors in isolated human trophoblast. Placenta, 1997, 18, 657-665.

[22] Hood, J. D., Meininger, C. J., Ziche, M., et al.: VEGF upregulates ecNOS message, protein, and NO production in human endothelial cells. Am. J. Physiol., 1998, 274, H1054-H1058.

[23] Jackson, M. R., Walsh, A. J., Morrow, R. J., et al.: Reduced placental villous tree elaboration in small-for-gestational-age pregnancies: relationship with umbilical artery Doppler waveforms. Am. J. Obstet. Gynecol., 1995, 172, 518-525.

[24] Teasdale, F.: Idiopathic intrauterine growth retardation: histomorphometry of the human placenta. Placenta, 1984, 5, 83-92.

[25] Andraweera, P. H., Dekker, G. A., Roberts, C. T.: The vascular endothelial growth factor family in adverse pregnancy outcomes. Hum. Reprod Update, 2012, 18, 436-457.

[26] Luttun, A., Brusselmans, K., Fukao, H., et al.: Loss of placental growth factor protects mice against vascular permeability in pathological conditions. Biochem. Biophys. Res. Commun., 2002, 295, 428-434

[27] Odorisio, T., Schietroma, C., Zaccaria, M. L., et al.: Mice overexpressing placenta growth factor exhibit increased vascularization and vessel permeability. J. Cell Sci., 2002, 115, 2559-2567.

[28] Rutland, C. S., Mukhopadhyay, M., Underwood, S., et al.: Induc tion of intrauterine growth restriction by reducing placental vascular growth with the angioinhibin TNP-470. Biol. Reprod., $2005,73,1164-1173$

[29] Garza-Veloz, I., Castruita-De la Rosa, C., Cortes-Flores, R., et al.: No association between polymorphisms/haplotypes of the vascular endothelial growth factor gene and preeclampsia. BMC Pregnancy Childbirth, 2011, 11, 35.

[30] Cerdeira, A. S., Karumanchi, S. A.: Angiogenic factors in preec lampsia and related disorders. Cold Spring Harb. Perspect. Med., 2012, 2(11), a006585.

[31] Szentpéteri, I., Rab, A., Kornya, L., et al.: Gene expression patterns of vascular endothelial growth factor (VEGF-A) in human placenta from pregnancies with intrauterine growth restriction. J. Matern. Fetal Neonatal Med., 2013, 26, 984-989.

[32] Gougos, A., Letarte, M.: Primary structure of endoglin; an RDGcontaining glycoprotein of human endothelial cells. J. Biol. Chem., 1990, 265, 8361-8364.

[33] Ten Dijke, P., Goumans, M., Pardali, E.: Endoglin in angiogenesis and vascular diseases. Angiogenesis, 2008, 11, 79-89.

[34] Van Laake, L. W., van den Driesche, S., Post, S., et al.: Endoglin has a crucial role in blood cell-mediated vascular repair. Circulation, 2006, 114, 2288-2297.

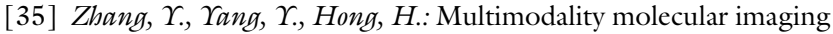
of CD105 (endoglin) expression. Int. J. Clin. Exp. Med., 2011, $4,32-42$.

[36] Ten Dijke, P., Arthur, H. M.: Extracellular controll of TGF-beta signalling in vascular development and disease. Nat. Rev. Mol. Cell Biol., 2007, 8, 857-869.

[37] Arthur, H. M., Ure, J., Smith, A. J., et al.: Endoglin, an ancillary TGF-beta receptor, is required for extraembryonic angiogenesis and plays a key role in heart development. Dev. Biol., 2000, 217, $42-53$.

[38] Yinon, Y., Kingdom, J. C., Odutayo, A., et al.: Vascular dysfunction in women with a history of preeclampsia and intrauterine growth restriction. Circulation, 2010, 122, 1846-1853

[39] Wallner, W., Sengenberger, R., Strick, R., et al.: Angiogenetic growth factors in maternal and fetal serum in pregnancies complicated by intrauterine growth restriction. Clin. Sci., 2007, 112, $51-57$.

[40] Asvold, B. O., Vatten, L. J., Romundstad, P. R., et al.: Angiogenic factors in maternal circulation and the risk of severe fetal growth restriction. Am. J. Epidemiol., 2011, 173, 630-639. 
[41] Laskowska, M., Laskowska, K., Oleszczuk, J.: Endoglin in pregnancy complicated by fetal intrauterine growth restriction in normotensive and preeclamptic pregnant women: a comparison between preeclamptic patients with appropriate-for-gestational-age weight infants and heatlhy pregnant women. J. Matern. Fetal Neonatal Med., 2012, 25, 806-811.

[42] Ramsay, J. E., Ferrell, W. R., Crawford, L., et al.: Divergent metabolic and vascular phenotypes in preeclampsia and intrauterine growth restriction. J. Hypertens., 2004, 22, 2177-2183.

[43] Stepan, H., Krämer, T., Faber, R.: Maternal plasma concentrations of soluble endoglin in pregnancies with intrauterine growth restriction. J. Clin. Endocrinol. Metab., 2007, 92, 2831-2834.

[44] Yinon, $\Upsilon$., Nevo, O., Xu, J., et al.: Severe intrauterine growth restriction pregnancies have increased placental endoglin levels. Am. J. Pathol., 2008, 172, 77-85.

[45] Szentpéteri, I., Rab, A., Kornya, L., et al.: Placental gene expression patterns of endoglin (CD105) in intrauterine growth restriction. J. Matern. Fetal Neonatal Med., 2014, 27, 350-354

[46] Jeyabalan, A., McGonigal, S., Gilmour, C., et al.: Circulating and placental endoglin concentrations in pregnancies complicated by intrauterine growth restriction and preeclampsia. Placenta, 2008, $29,555-563$

[47] Elhawary, T. M., El-Bendary, A. S., Demerdash, H.: Maternal serum endoglin as an early marker of preeclampsia in high risk patients. Int. J. Womens Health, 2012, 4, 521-525.

[48] Maglione, D., Guerriero, V., Viglietto, G., et al.: Two alternative $\mathrm{mRNAs}$ coding for the angiogenic factor, placenta growth factor (PlGF), are transcribed from a single gene of chromosome 14 . Oncogene, 1993, 8, 925-931.

[49] Torry, D. S., Hinrichs, M., Torry, R. J.: Determinants of placental vascularity. Am. J. Reprod. Immunol., 2004, 51, 257-268.

[50] Weinstein, L.: Syndrome of hemolysis, elevated liver enzymes and low platelet count: a severe consequence of hypertension in pregnancy. Am. J. Obstet. Gynecol., 1982, 142, 159-167.
[51] Dekker, G., Sibai, B.: Primary, secondary and tertiary prevention of preeclampsia. Lancet, 2001, 357, 209-215.

[52] Sibai, B., Dekker, G., Kupferminc, M.: Preeclampsia. Lancet, 2005, 365, 785-799.

[53] Roberts, D. J., Post, M.: The placenta in pre-eclampsia and intrauterine growth restriction. J. Clin. Pathol., 2008, 61, 1254-1260.

[54] Khong, T., de Wolf, F., Robertson, W., et al.: Inadequate maternal vascular response to placentation in pregnancies complicated by preeclampsia and by small-for-gestational age infants. Br. J. Obstet. Gynecol., 1986, 93, 1049-1059.

[55] Makrydimas, G., Sotiriadis, A., Savvidou, M., et al.: Physiological distribution of placental growth factor and soluble Flt- 1 in early pregnancy. Prenat. Diagn., 2008, 28, 175-179.

[56] Levine, R., Lam, C., Qian, C., et al.: Soluble endoglin and other circulating antiangiogenic factors in preeclampsia. N. Engl. J. Med., 2006, 355, 992-1005.

[57] Poon, L. C., Zaragoza, E., Akolekar, R., et al.: Maternal serum placental growth factor (PlGF) in small for gestational age pregnancy at 11 to 13 weeks of gestation. Prenat. Diagn., 2008, 28, $1110-1115$.

[58] Gomez-Roig, M. D., Mazarico, E., Sabria, J., et al.: Use of placental growth factor and uterine artery Doppler pulsatility index in pregnancies involving intrauterine fetal growth restriction or preeclampsia to predict perinatal outcomes. Gynecol. Obstet. Invest., 2015, 80, 99-105.

[59] Joó, J. G., Rigó, J. Jr., Börzsönyi, B., et al.: Placental gene expression of the placental growth factor (PlGF) in intrauterine growth restriction. J. Matern. Fetal Neonatal Med., 2016 Sep 5. 1-5. [Epub ahead of print]

(Joó József Gábor dr., Budapest, Baross u. 27., 1088 e-mail: joogabor@hotmail.com)

\section{Tisztelt Szerzőink, Olvasóink!}

Az Orvosi Hetilapban megjelenő/megjelent közlemények elérhetőségére több lehetőség kínálkozik.

Rendelhető különlenyomat, melynek áráról bővebben a www.akkrt.hu honlapon (Folyóirat Szerzőknek, Különlenyomat menüpont alatt) vagy Szerkesztőségünkben tájékozódhatnak.

A közlemények megvásárolhatók pdf-formátumban is, illetve igényelhető Optional Open Article (www.oopenart.com).

Adott dij ellenében az online közlemények bárki számára hozzáférhetők honlapunkon (a közlemények külön linket kapnak, így más oldalról is linkelhetővé válnak).

Bővebb információ a hirdetes@akkrt.hu címen vagy különlenyomat rendelése esetén a Szerkesztőségtől kérhető. 